\title{
ANALYSING ASSOCIATION BETWEEN ANTHROPOMETRIC INDICATORS OF INSULIN RESISTANCE AND INSULIN-LIKE GROWTH FACTOR-1 IN PATIENTS WITH NODULAR GOITER*
}

\author{
O. S. Miroshnichenko ${ }^{1}$, M. R. Mykytyuk ${ }^{1,2}$, I. V. Cherniavska ${ }^{1}$, \\ V. M. Dubovyk ${ }^{1}$, N. Yu. Seliukova ${ }^{1}$, O. G. Dorosh ${ }^{1}$, V. L. Gerasymenko', M. Ye. Sazonov ${ }^{1}$ \\ ${ }^{1} S I$ «V. Danilevsky Institute for endocrine pathology problems National Academy \\ of Medical sciences of Ukrainen, Kharkov, Ukraine \\ ${ }^{2}$ Kharkiv Medical Academy of postgraduate education of the Ministry of health of Ukraine, \\ Kharkov, Ukraine \\ myronchik@gmail.com
}

Both solitary and multiple thyroid nodules are very commonly seen in clinical practice. This is important, as thyroid cancer occurs in approximately $5 \%$ of these nodules [1]. The prevalence of thyroid nodular disease in the United States is $7 \%$, if it is detected by bimanual palpation of the thyroid gland and is $50 \%$ if detected by ultrasonography [2].

Publications suggesting that thyroid nodule might be associated with insulin resistance (IR) and metabolic syndrome (MS) are quite interesting. IR is considered a central pathological link among these risk factors [3]. Thyroid hormones have a profound effect on energy homeostasis, lipid and glucose metabolism, and blood pressure. Previous reports investigated functional and morphological alterations of the thyroid gland in relation to obesity [4-6]. Additionally, in a very recent report, increased thyroid volume and nodule prevalence were also reported in patients with IR in an iodinesufficient area [7].

Previous studies support the concept that insulin concurrently functions with thyroidstimulating hormone (TSH) as a growth factor and stimulates thyroid cell proliferation. This effect is partially mediated via insulin growth factor-1 (IGF-1) - dependent mechanisms; therefore, IGF-1 might be involved in the pathogenesis of thyroid morphological abnormalities $[8,9]$. In this context, it is known that receptors for IGF-1 and IGF-2 are overexpressed in

* The work was performed in the Department of Clinical Endocrinology of the State Institution «V. Danilevsky Institute for endocrine pathology problems National Academy of Medical sciences of Ukraine» within the framework of the topic «To develop pathogenetically substantiated differentiated algorithms of diagnostics and treatment of neoplasms of thyroid and adrenal glands» (state registration number 0119U10244).

The institution that finances the study is the National Academy of Medical Sciences of Ukraine.

The authors guarantee full responsibility for everything published in the article.

The authors guarantee that there is no conflict of interest and their own financial interest when performing the work and writing the article.

The manuscript was received by the editorial staff 15.09.2021. 
cell lines thyroid cancer, acting as the main mitogenic and anti-apoptotic factors of cells cancer $[10,11]$.

Insulin can act as a factor of the thyroid proliferation, a fact that has been shown in cell culture, leading to growth of the thyroid gland and, therefore, under certain conditions trigger a nodular thyroid disease [7]. Several recent studies have focused on the relationships between MS, thyroid growth in IR, increases in the thyroid nodule rate, and increases in the papillary thyroid cancer rate [12-14]. The Homeostasis Model Assessment of IR has been shown to be positively associated with thyroid volume and the presence of a nodule [15].

Recently, there have been numerous published reports associating increased circumferences of certain regions of the human body with IR or increased risk of cardiovascular disease [16]. Some studies have analyzed the efficacy of anthropometric indicators in predicting IR as they are more economic and accessible.

Purpose of the study: Analyze the association between anthropometric indicators of IR and the level of IGF-1 in the blood in patients with nodular goiter.

\section{MATERIALS AND METHODS}

The authors conducted the study in accordance with the legislation of Ukraine and the principles of the Helsinki Declaration of Human Rights. The Ethics Commission of the State Institution «V. Danilevsky Institute for endocrine pathology problems National Academy of Medical sciences of Ukraine» considered and approved the design of the study, information for the patient and the form of the informed consent to participate in the study.

In the study, the authors examined 73 patients with euthyroid single-node (SNG) (group 1) $(\mathrm{n}=34)$ and multinodular goiter $(\mathrm{MNG})$ (group 2) $(\mathrm{n}=39)$ aged from 17 to 74 years $(51.0 \pm 10.6$ years). According to gender, the respondents were distributed as follows: 15 men $(20.5 \%)$ and 58 women $(79.5 \%)$, respectively. The comparison group consisted of 42 healthy volunteers. Criteria for inclusion in the study were: the patient's age from 16 to 80 years, presence of one or more tumors in the thyroid gland. Exclusion criteria were: presence of hormonal dysfunction (hypothyroidism, thyrotoxicosis), exacerbation of chronic diseases or acute diseases at the time of examination, pregnancy.

Anthropometric data: Height (m) was measured using a medical mechanical height meter Harpenden, weight $(\mathrm{kg})$ - on electronic scales Beurer GS 20 Summer Sky with a measurement accuracy of up to $100 \mathrm{~g}$ (maximum weight $180 \mathrm{~kg}$ ), waist circumference (WC) was measured at the midpoint between the lower margin of the last palpable rib and the top of the iliac crest using a stretch-resistant tape, hip circumference $(\mathrm{HC})(\mathrm{cm})$ - a centimeter tape at the level of a large spit.
Calculation of anthropometric indices: determined the ratio of $\mathrm{WC}$ to $\mathrm{HC}$ (WC/HC) (c.u.); Body Mass Index (BMI) $\left(\mathrm{kg} / \mathrm{m}^{2}\right)$ was assessed by dividing the person's weight by height squared. According to WHO, BMI of 18.5 to $24.9 \mathrm{~kg} / \mathrm{m}^{2}$ defines normal weight, one of 25 to $29.9 \mathrm{~kg} / \mathrm{m}^{2}$ defines overweight and greater than or equal to 30 obesity [17]; WC/Height (WHtR) (c.u) was calculated as the ratio of $\mathrm{WC}(\mathrm{cm})$ to the height $(\mathrm{m})$ of patient [18]; ABSI (A Body Shape Index) (AU) was determined by the N.Y. Krakauer \& J.C. Krakauer formula [19]:

$$
A B S I=\frac{W C}{\left(B M I^{2 / 3} \times H e i g h t^{1 / 2}\right)}
$$

Body fat distribution (BFD) was calculated as product BMI $\left(\mathrm{kg} / \mathrm{m}^{2}\right)$ on $\mathrm{WC} / \mathrm{TC}$.

BRI (Body Roundness Index) (c.u) was calculated by the formula [20]:

$$
B R I=364,2-365,5 * \sqrt{1-\left(\frac{\frac{W C_{(m)}}{2 \pi}}{\left(0,5 * \text { Height }_{(m)}\right)}\right)^{2}}
$$

CI (conicity index) (c.u.) was determined by the R. Valdez e formula [21]:

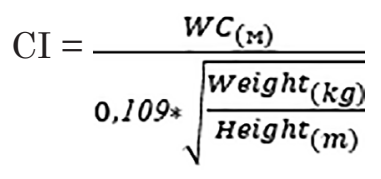

Abdominal volume index (AVI) was calculated by the F. Guerrero-Romero, M. Rodríguez-Morán formula [22]:

$\mathrm{AVI}=\frac{2 *\left(W C_{(\mathrm{cm})}\right)^{2}+0,7 *\left(W C_{(\mathrm{cm})}-H C_{(\mathrm{cm})}\right)^{2}}{1000}$ 
Body adiposity index $(\mathrm{BAI})=$

$$
=\frac{W C_{(\mathrm{cm})}}{\text { Height }_{(\mathrm{m})} 3 / 2}-18[23]
$$

Abdominal type of obesity was determined in women with $\mathrm{WC} / \mathrm{TC}$ value $>0.85$, in men -> 0.9; WHO classification criteria (2000) were used to assess BMI [17].

Venous blood samples were obtained from the cubital vein after 8 hours of fasting. Concentration of IGF-1 (ng/ml) in blood was determined by a solid-phase sandwich method using kits "Human IGF-I ELISA Kit» on the Stat Fax 4700. Levels of thyroid hormones (TSH, free thyroxine ( $\mathrm{fT}_{4}$ ) and triiodothyron $\mathrm{fT}_{3}$ )) in blood serum were determined by ELISA (Germany).

Thyroid volume, its structure, number, size and location of foci was assessed by ultrasonography on an ultrasonic complex Aloka SSD-1100 (Japan) using a linear sensor $7.5 \mathrm{MHz}$, measuring range $0-70 \mathrm{~mm}$ vertically and $50 \mathrm{~mm}$ horizontally. The allowable mea- surement error was $\pm 2 \mathrm{~mm}$. The volume of thyroid lobes was determined by J. Brunn [24].

The results were statistically processed using the software package STATISTICA (StatSoft, version 10.1, USA). The normality of variables distribution was determined using the Shapiro-Wilk test. The Kruskal-Wallis test was used to compare several groups with an abnormal distribution of variables. Regression analysis was used to determine the relationship between the studied indicators and the normal distribution of variables. Associations between dependent and independent variables were analyzed by multiple regression analysis. The results are presented in a tabular form and include such model characteristics as regression coefficient (B), standardized regression coefficient (B) and determination coefficient (R2). The null hypotheses were tested at the significance level $\mathrm{P} \leq 0.05$. The obtained results are presented in the tables in the form of $\bar{X} \pm \mathrm{s}$, where $\bar{X}$ is an arithmetic mean, s - is a standard deviation.

\section{RESULTS AND THEIR DISCUSSION}

Analysis of the studied anthropometric indicators of IR did not reveal significant differences between the groups of patients with SNG and MNG (Table 1).

The authors have found that in the total sample of patients with nodular goiter IGF-1 concentration level in blood is nonlinearly negatively associated with BMI $(r=-0.30$; $\mathrm{P}=0.016)$, WC $(r=-0.26 ; \mathrm{P}=0.036)$, WHtR index $(r=-0.30 ; \mathrm{P}=0.020)$, AVI $(r=-0.27$; $\mathrm{P}=0.03)$, ABSI $(r=-0.31 ; \mathrm{P}=0.015)$, nonlinearly positive with $\mathrm{BFD}(\mathrm{r}=0.27$; $\mathrm{P}=0.033)$, BRI ( $r=0.29 ; \mathrm{P}=0.02)$ and linearly positive with BAI ( $r=0.36 ; \mathrm{P}=0.004)$ (Fig. 1$)$.

In the total pool of patients, thyroid volume is linearly positively associated with age $(r=$ $0.35 ; \mathrm{P}=0.009)$, nonlinearly positively with WC/HC ( $r=0.43 ; \mathrm{P}=0.001), \mathrm{BFD}(\mathrm{r}=0.26 ; \mathrm{P}$ $=0.06)$ and CI $(r=0.31 ; \mathrm{P}=0.02)$. In patients with nodular goiter with $\mathrm{BMI} \geq 35 \mathrm{~kg} / \mathrm{m}^{2}$ thyroid volume was linearly positively associated with BMI ( $\mathrm{r}=0.71 ; \mathrm{P}=0.049)$.

Analysis results of the studied IR anthropometric indicators in groups of patients with nodular goiter, considering IGF-1concentration level, are given in Table 2.
It has been found that patients with nodular goiter with a level of IGF-1 concentration exceeding the upper limit of the reference interval for sex and age, have significantly higher BMI and anthropometric indicators of IR WHtR, ABSI, BFD and BAI, indicating a more pronounced IR in this group.

The authors have determined that in the group of patients with nodular goiter with the level of IRF-1 concentration above the upper limit of the reference value thyroid volume is nonlinearly positively associated with $\mathrm{WC} / \mathrm{HC}$ $(r=0.71 ; \mathrm{P}=0.01)$, BAI $(r=0.66 ; \mathrm{P}=0.03)$ and nonlinearly negative with $\mathrm{BFD}(\mathrm{r}=-0.52$; $\mathrm{P}=0.01)$.

In order to assess the significance of IR influence (according to anthropometric indices) on IGF-1 level in the blood of patients with nodular goiter, we performed a multiple regression analysis, where the dependent variable was the level of IGF-1 in the blood, and independent - BMI, WHtR, ABSI, BFD, BRI, BAI (Table 3, model 1-3). To assess the significance of the IR effect on the $\mathrm{V}$ thyroid gland, we performed a multiple regression analysis, where the dependent variable was V thyroid gland, 
Anthropometric indicators of IR and laboratory parameters in patients with nodular goiter

\begin{tabular}{|c|c|c|c|}
\hline Index & $\begin{array}{c}\text { Comparative group } \\
(\mathrm{n}=42)\end{array}$ & $\begin{array}{c}\text { SNG } \\
\text { group } 1(\mathrm{n}=34)\end{array}$ & $\begin{array}{c}\text { MNG } \\
\text { group } 2(n=39)\end{array}$ \\
\hline Age, years & $55,95 \pm 8,25$ & $\begin{array}{l}47,26 \pm 14,8 \\
\mathrm{P}_{1-2}=0,002\end{array}$ & $\begin{array}{c}54,36 \pm 9,71 \\
P_{2-3}=0,017\end{array}$ \\
\hline $\mathrm{BMI}, \mathrm{kg} / \mathrm{m}^{2}$ & $27,68 \pm 4,19$ & $28,72 \pm 5,29$ & $30,19 \pm 5,85$ \\
\hline $\mathrm{WC}, \mathrm{cm}$ & $91,93 \pm 11,08$ & $91,38 \pm 13,68$ & $92,46 \pm 13,55$ \\
\hline WC/HC, c.u & $0,89 \pm 0,1$ & $0,87 \pm 0,1$ & $0,84 \pm 0,08$ \\
\hline ABSI, c.u & $0,31 \pm 0,08$ & $0,29 \pm 0,09$ & $0,27 \pm 0,07$ \\
\hline BFD, c.u & $31,77 \pm 4,73$ & $33,42 \pm 6,23$ & $\begin{array}{c}36,04 \pm 6,42 \\
\mathrm{P}_{2-3}=0,08\end{array}$ \\
\hline WHtR, c.u & $55,93 \pm 6,93$ & $56,16 \pm 8,81$ & $56,35 \pm 8,45$ \\
\hline BRI, c.u & $4,64 \pm 1,46$ & $4,74 \pm 1,84$ & $4,77 \pm 1,82$ \\
\hline IC, c.u & $1,25 \pm 0,09$ & $1,23 \pm 0,10$ & $1,21 \pm 0,10$ \\
\hline AVI, c.u & $17,33 \pm 3,85$ & $17,28 \pm 4,79$ & $17,73 \pm 5,04$ \\
\hline BAI, c.u & $32,00 \pm 5,22$ & $33,04 \pm 6,89$ & $34,39 \pm 5,98$ \\
\hline TTГ, mIU/L & $2,09 \pm 0,92$ & $2,42 \pm 0,83$ & $2,59 \pm 1,05$ \\
\hline $\mathrm{fT}_{4}, \mathrm{mIU} / \mathrm{L}$ & $15,80 \pm 2,10$ & $15,57 \pm 2,60$ & $16,34 \pm 3,78$ \\
\hline $\mathrm{fT}_{3}, \mathrm{mIU} / \mathrm{L}$ & $5,28 \pm 1,64$ & $5,35 \pm 1,01$ & $4,80 \pm 2,03$ \\
\hline IGF-1, ng/ml & $239,33 \pm 97,88$ & $232,53 \pm 107,37$ & $258,78 \pm 131,57$ \\
\hline Thyroid volume, $\mathrm{cm}^{3}$ & $14,60 \pm 1,86$ & $18,82 \pm 2,77$ & $28,06 \pm 12,51$ \\
\hline
\end{tabular}

Results of the analysis of IR anthropometric indicators and laboratory parameters in patients with nodular goiter, considering IGF-1 concentration level in the blood

\begin{tabular}{|c|c|c|c|}
\hline \multirow{2}{*}{ Parameter } & \multicolumn{2}{|c|}{ Patients with nodular goiter } & \multirow{2}{*}{$\mathbf{P}$} \\
\hline & IGF-1 normal $(n=51)$ & IGF-1 high $(n=17)$ & \\
\hline Age, years & $50,47 \pm 13,19$ & $51,94 \pm 13,16$ & 0,70 \\
\hline $\mathrm{BMI}, \mathrm{kg} / \mathrm{m}^{2}$ & $28,76 \pm 5,71$ & $32,42 \pm 4,58$ & 0,02 \\
\hline $\mathrm{WC}, \mathrm{cm}$ & $90,96 \pm 14,63$ & $97,24 \pm 8,52$ & 0,10 \\
\hline $\mathrm{WC} / \mathrm{HC}, \mathrm{c.u}$ & $0,85 \pm 0,09$ & $0,86 \pm 0,08$ & 0,75 \\
\hline WHtR, c.u & $55,43 \pm 9,06$ & $60,48 \pm 5,78$ & 0,037 \\
\hline ABSI, c.u & $0,29 \pm 0,07$ & $0,23 \pm 0,06$ & 0,01 \\
\hline BFD, c.u & $33,98 \pm 5,88$ & $38,19 \pm 6,72$ & 0,02 \\
\hline BRI, c.u & $4,60 \pm 1,95$ & $5,61 \pm 1,31$ & 0,053 \\
\hline IC, c.u & $1,22 \pm 0,11$ & $1,24 \pm 0,07$ & 0,47 \\
\hline AVI, c.u & $17,21 \pm 5,30$ & $19,30 \pm 3,39$ & 0,14 \\
\hline BAI, c.u & $32,95 \pm 5,27$ & $37,98 \pm 6,13$ & 0,002 \\
\hline $\mathrm{TT}, \mathrm{mIU} / \mathrm{L}$ & $1,54 \pm 0,83$ & $2,31 \pm 0,57$ & 0,68 \\
\hline $\mathrm{fT}_{4}, \mathrm{mIU} / \mathrm{L}$ & $10,40 \pm 7,12$ & $26,69 \pm 36,71$ & 0,096 \\
\hline $\mathrm{fT}_{3}, \mathrm{mIU} / \mathrm{L}$ & $4,27 \pm 1,71$ & $4,58 \pm 0,17$ & 0,77 \\
\hline IGF-1, ng/ml & $180,10 \pm 70,97$ & $394,57 \pm 77,92$ & 0,00001 \\
\hline Thyroid volume, $\mathrm{cm}^{3}$ & $23,73 \pm 2,06$ & $21,07 \pm 6,17$ & 0,06 \\
\hline
\end{tabular}




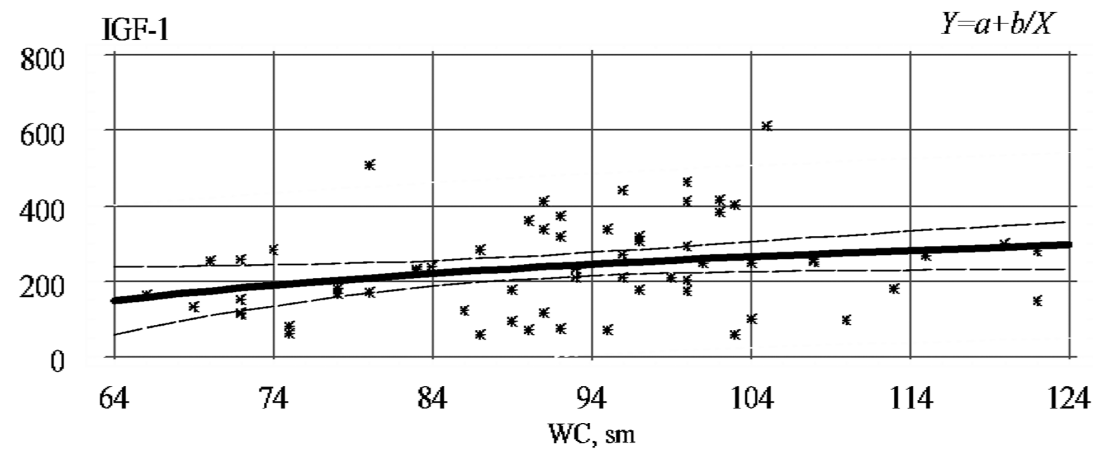

IfF-1
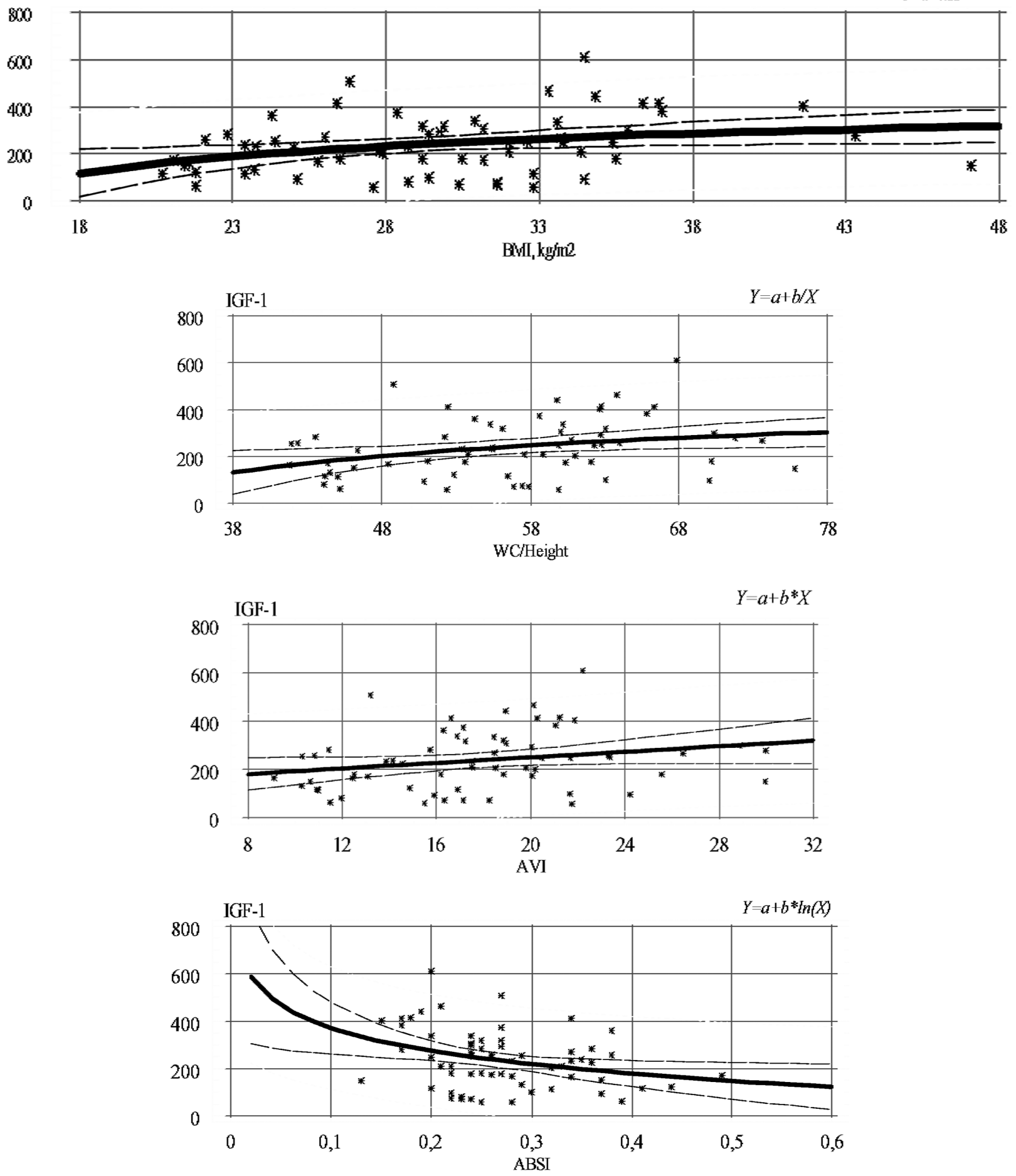

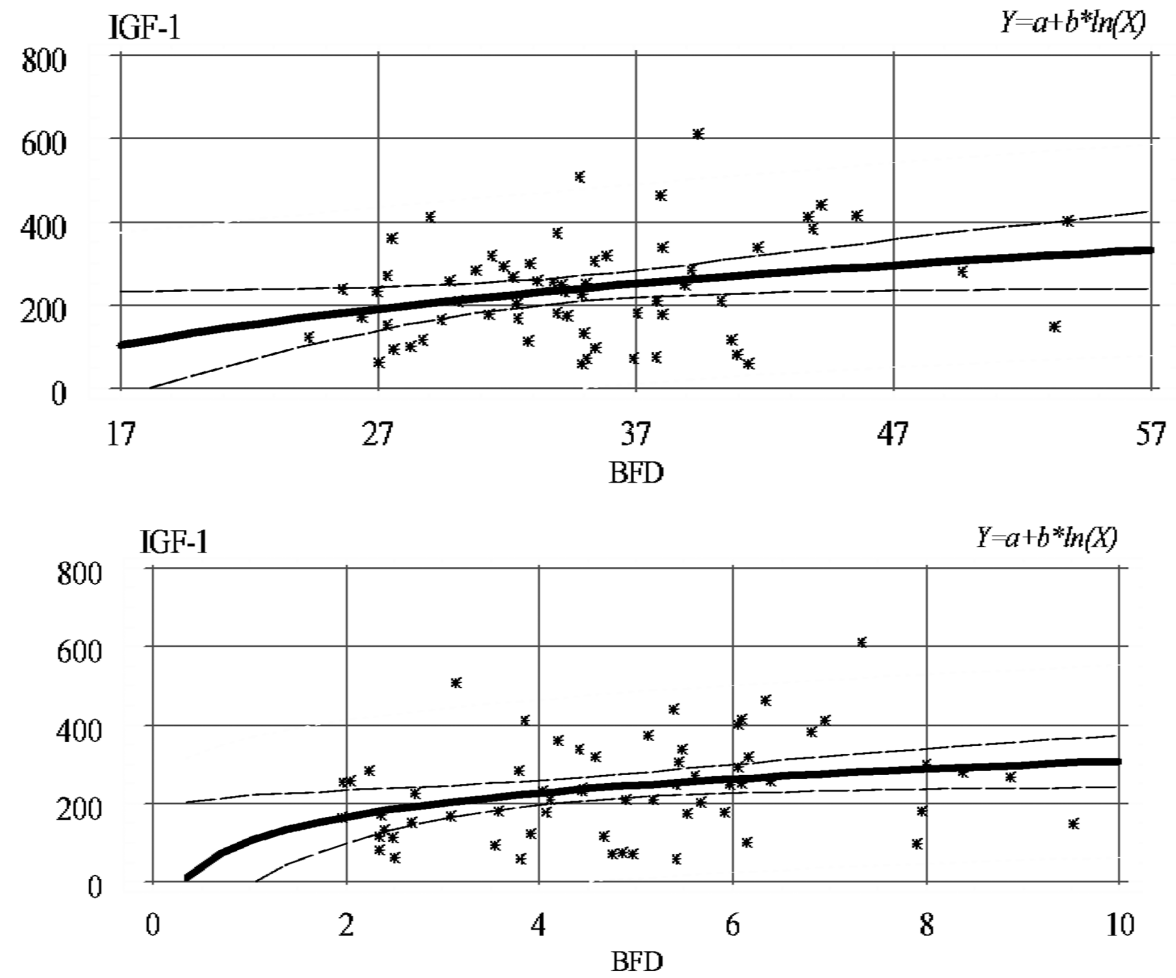

IGF-1

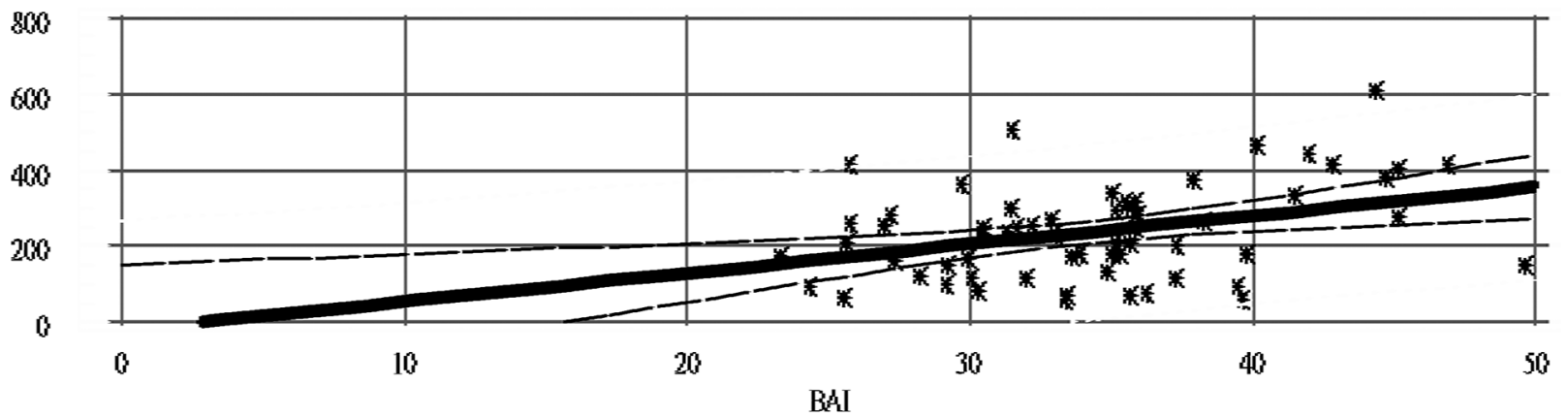

Fig. 1. Dependence of IGF-1 concentration level on anthropometric indicators of insulin resistance in patients with nodular goiter.

and independent - IGF-1, BMI, WHtR, ABSI, BFD, BRI, BAI (Table 3, model 4-6).

It has been found that BAI explains $82.37 \%$ of the IGF-1 concentration level variance in the general group and more than $90 \%$ of the variance of its level in groups of patients with nodular goiter with a high level of IGF-1 with/ without obesity (Table 3). That is, in patients with nodular goiter, the BAI value is a predictor of increased levels of IGF-1. Moreover, in patients with a high level of IGF-1 and obesity, the predictor of increased thyroid volume is BRI, which explains $81.14 \%$ of its volume variance (Table 3). J. Feng, S. He, X. Chen proved that BRI showed a reasonable potential to serve as an alternative anthropometric index to detect IR [25].

IGF-1 is actively involved in the TSHmediated proliferation of thyrocytes. Insulin/ IGF-1-signaling pathway has long been known to modulate the regulation of thyroid gene expression and might be considered as additional important factors in thyrocyte proliferation and differentiation [26, 27].

In obesity, the release of proinflammatory factors from adipose tissue increases, while the release of adipokines decreases. Proinflammatory factors act as signal mediators of peritumoral tissue in tumor growth and progression [26, 27]. 
Results of a multiple regression analysis

\begin{tabular}{|c|c|c|c|c|c|c|}
\hline \multicolumn{2}{|c|}{ Variable } & \multicolumn{4}{|c|}{ Statistical index } & \multirow{2}{*}{$\mathbf{R}^{2}, \%$} \\
\hline dependent & independent & B & $\beta$ & $\mathbf{t}$ & $\mathbf{P}$ & \\
\hline \multirow{7}{*}{ IGF-1, ng/ml } & \multicolumn{6}{|c|}{ Model 1 (total sample) } \\
\hline & BAI, c.u & 6,84 & 0,39 & 17,69 & 0,00001 & 82,37 \\
\hline & \multicolumn{6}{|c|}{ Model 2 (high IGF-1) } \\
\hline & ABSI, c.u & 422,45 & 204,5 & 2,07 & 0,056 & \multirow{2}{*}{96,68} \\
\hline & BAI, c.u & 7,77 & 1,28 & 6,06 & 0,00001 & \\
\hline & \multicolumn{6}{|c|}{ Model 3 (high IGF-1\&obesity) } \\
\hline & BAI, c.u & 9,99 & 0,56 & 17,84 & 0,00001 & 96,08 \\
\hline \multirow{7}{*}{ Thyroid volume, $\mathrm{m}^{3}$} & \multicolumn{6}{|c|}{ Model 4 (total sample) } \\
\hline & WHtR, c.u & $-1,66$ & 0,41 & 4,00 & 0,0002 & \multirow{2}{*}{67,29} \\
\hline & BAI, c.u & $-2,04$ & 0,67 & $-3,03$ & 0,004 & \\
\hline & \multicolumn{6}{|c|}{ Model 5 (high IGF-1) } \\
\hline & ABSI, c.u & 89,23 & 17,98 & 4,96 & 0,0006 & 71,13 \\
\hline & \multicolumn{6}{|c|}{ Model 6 (high IGF-1\&obesity) } \\
\hline & BRI, c.u & 2,85 & 0,52 & 5,49 & 0,0009 & 81,14 \\
\hline
\end{tabular}

The results obtained by P. A. Sousa, M. Vaisman, J. R. Carneiro et al., testify in favor of the hypothesis of a direct connection between IR and thyroid volume [28]. According to J. Rezzonico et al., patients with IR have larger thyroid volumes and higher risk of thyroid nodules formation [7].

Previous studies have shown that thyroid volume increases with increasing BMI or body surface area [29]. Our results of significant associations between thyroid volume and higher BMI are in line with the observations from many other studies [30].

Although BMI does not measure body fat directly, it can be an acceptable indicator of body adiposity [31]. Lee M. H., Lee J. U., Joung K. H., et al. advanced a hypothesize that patients with higher body weight may have the tendency to accumulate fat in the thyroid tissue, which leads to a larger thyroid volume [32]. The authors proved the connection between obesity and morphological changes in the thyroid gland, suggesting that excessive adiposity leads to expansion of the interfollicular adipose depot or steatosis in thyroid follicular cells (thyroid steatosis) [32]. Furthermore, high BMI leads to hyperinsulinemia and IR that also contribute to an increased thyroid cell proliferation and goiter formation. It is possible that other important growth factors stimulate thyroid cell structural transformation and proliferation independently of BMI. Moreover, complex interactions between environmental and genetic factors are also involved in the etiology of thyroid nodules [33].

Thus, we can conclude that there is some association between intropometric IR indicators with IGF-1 and thyroid gland volume in patients with nodular goiter. According to the results of a multiple regression analysis, body adiposity index $(\mathrm{t}=17.69 ; \mathrm{P}=0.00001)$ and body roundness index $(\mathrm{t}=5.49 ; \mathrm{P}=0.0009)$ have the most significant effect on these studied indicators in patients with nodular goiter.

\section{CONCLUSIONS}

1. Patients with nodular goiter with the level of IGF-1 concentration in the blood above the sex-age norm have significantly higher values of anthropometric indicators IR (WHtR, ABSI, BFD and BAI), compared with patients with normal levels of this indicator.
2. In patients with nodular goiter with II degree obesity and above thyroid volume is significantly associated with BMI.

3. BAI is a predictor of increased levels of IGF-1 in the blood of patients with nodular goiter, regardless of obesity. 
4. BRI is a predictor of an increased thyroid volume in patients with nodular goiter with a high level of IGF-1 and obesity, which explains $81.14 \%$ variance of its volume.

\section{REFERENCES}

1. Pacini F, Schlumberger MJ. Pract Management Thyroid Cancer: 201-210. https://doi.org/10.1007/1-84628-013-3_17.

2. Hegedüs L. $N$ Engl J Med 2004;351(17): 1764-1771. https://doi.org/10.1056/NEJMcp031436.

3. Reaven GM. Diabetes 1988;37(12): 1595-1607. https:// doi.org/10.2337/diab.37.12.1595.

4. Sari R, Balci MK, Altunbas H, Karayalcin U. Clin Endocrinol (Oxf) 2003;59(2): 258-262. https://doi.org/10. 1046/j.1365-2265.2003.01836.x.

5. Michalaki MA, Vagenakis AG, Leonardou AS, et al. Thyroid 2006;16(1): 73-78. https://doi.org/10.1089/thy. 2006.16.73.

6. De Pergola G, Ciampolillo A, Paolotti S, et al. Clin Endocrinol (Oxf) 2007;67(2): 265-269. https://doi.org/10. 1111/j.1365-2265.2007.02874.x.

7. Rezzonico J, Rezzonico M, Pusiol E, et al. Thyroid 2008; 18(4): 461-464. https://doi.org/10.1089/thy.2007.0223.

8. Van Keymeulen A, Dumont JE, Roger PP. Biochem Biophys Res Commun 2000;279(1): 202-207. https://doi.org/ 10.1006/bbrc.2000.3910.

9. Kimura T, Dumont JE, Fusco A, Golstein J. Eur $J$ Endocrinol 1999;140(1): 94-103. https://doi.org/10.1530/ eje.0.1400094.

10. Frittitta L, Sciacca L, Catalfamo R, et al. Cancer 1999; 85(2): 492-498. https://doi.org/10.1002/(SICI)1097- 0142 (19990115)85:2\%3C492::AID-CNCR30\%3E3.0.CO;2-I.

11. Yasar HY, Ertuğrul O, Ertuğrul B, et al. Endocr Res 2011;36(4): 167-174. https://doi.org/10.3109/07435800.2 011.593011 .

12. Tsatsoulis A. J Clin Med 2018;7(3): 37. https://doi.org/ $10.3390 / \mathrm{jcm} 7030037$.

13. Răcătăianu N, Leach N, Bondor CI, et al. Arch Endocrinol Metab 2017;61(6): 575-583. https://doi.org/10. 1590/2359-3997000000306.

14. Tang Y, Yan T, Wang G, et al. Int J Endocrinol 2017; 2017: 1617458. https://doi.org/10.1155/2017/1617458.

15. Clinkscales W, Ong A, Nguyen S, et al. Otolaryngol Head Neck Surg 2017;156(3): 472-479. https://doi.org/10. $1177 / 0194599816685697$.

16. Polymeris A, Papapetrou PD. Hormones (Athens) 2021; 13. https://doi.org/10.1007/s42000-021-00296-0.

17. World Health Organ. Obesity: Preventing and managing the global epidemic. Report of a WHO consultation. Tech Rep Ser 2000: 894 p.
18. Krakauer NY, Krakauer JC. J Obes Weight Loss Ther 2014;4: 216.

19. Krakauer NY, Krakauer JC. PLoS One 2012;7(7): e39504. https://doi.org/10.1371/journal.pone.003950.

20. Thomas DM, Bredlau C, Bosy-Westphal A, et al. Obesity (Silver Spring) 2013;21(11): 2264-2271. https://doi.org/ 10.1002/oby.20408.

21. Valdez R. J Clin Epidemiol 1991;44(9): 955-956. https:// doi.org/10.1016/0895-4356(91)90059-i.

22. Guerrero-Romero F, Rodríguez-Morán M. Arch Med Res 2003;34(5): 428-432. https://doi.org/10.1016/S01884409(03)00073-0.

23. Bergman RN, Stefanovski D, Buchanan TA. Obesity 2011;19: 1083-1089. https://doi.org/10.1038/oby.2011.38.

24. Brunn J, Block U, Ruf G, et al. Dtsch Med Wochenschr 1981;106(41): 1338-1340. https://doi.org/10.1055/s-20081070506 .

25. Feng J, et al. Am J Med Sci 2019;357(2): 116-123. https://doi.org/10.1016/j.amjms.2018.11.006.

26. Mohan S, Baylink DJ, Pettis JL. J Clin Endocrinol Metab 1996;81(11): 3817-3820. https://doi.org/10.1210/ jcem.81.11.8923818.

27. Santisteban P, Acebrón A, Polycarpou-Schwarz M, Di Lauro R. Mol Endocrinol 1992;6(8): 1310-1307. https:// doi.org/10.1210/mend.6.8.1406708.

28. Sousa PA, Vaisman M, Carneiro JR, et al. Endocrinol Metabol 2013;57(2): 120-125. https://doi.org/10.1590/ s0004-27302013000200004.

29. Turcios S, Lence-Anta JJ, Santana JL, et al. Eur Thyroid J 2015;4(1): 55-61. https://doi.org/10.1159/000371346.

30. Kayastha P, Paudel S, Shrestha D, et al. J Institute Med 2010;32(2): 36-43.

31. Steinberger J, Jacobs DR, Raatz S. Int J Obes (Lond) 2005;29(11): 1346-1352. https://doi.org/10.1038/sj.ijo. 0803026 .

32. Lee MH, Lee JU, Joung KH, et al. Endocrinology 2015; 156(3): 1181-1193. https://doi.org/10.1210/en.2014-1670.

33. Hegedüs L, Bonnema SJ, Bennedbaek FN. Endocr Rev 2003;24(1): 102-132. https://doi.org/10.1210/er.2002-0016. 


\title{
ANALYSING ASSOCIATION BETWEEN ANTHROPOMETRIC INDICATORS OF INSULIN RESISTANCE AND INSULIN-LIKE GROWTH FACTOR-1 \\ IN PATIENTS WITH NODULAR GOITER
}

O. S. Miroshnichenko ${ }^{1}$, M. R. Mykytyuk ${ }^{1,2}$, I. V. Cherniavska ${ }^{1}$,

V. M. Dubovyk ${ }^{1}$, N. Yu. Seliukova ${ }^{1}$, O. G. Dorosh ${ }^{1}$, V. L. Gerasymenko ${ }^{1}$, M. Ye. Sazonov ${ }^{1}$

${ }^{1} S I$ "V. Danilevsky Institute for endocrine pathology problems

National Academy of Medical sciences of Ukraine", Kharkov, Ukraine

${ }^{2}$ Kharkiv Medical Academy of postgraduate education of the Ministry of health of Ukraine,

Kharkov, Ukraine

myronchik@gmail.com

Publications suggesting that thyroid nodule might be associated with insulin resistance (IR) and metabolic syndrome are quite interesting. In a very recent report, increased thyroid volume and nodule prevalence were also reported in patients with IR in an iodine-sufficient area. The purpose of the work is to analyze the association between anthropometric indicators IR and IGF-1 in patients with nodular goiter.

Materials and methods. During the study the authors examined 73 patients with euthyroid singlenode $(\mathrm{n}=34)$ and multinodular goiter $(\mathrm{n}=39)$ aged 17 to 74 years $(51.0 \pm 10.6$ years $)$, determining WC, WC/HC, BMI, WHtR, ABSI, BFD, BRI, CI, AVI, BAI, IGF-1, TSH, fT4, fT3. Thyroid volume, its structure, number, size and location of foci was assessed by an ultrasonic complex Aloka SSD-1100 (Japan), using a linear sensor 7.5 MHz.

Results. In the total number of patients with nodular goiter, IGF-1 is nonlinearly negatively associated with BMI $(r=-0.30 ; \mathrm{P}=0.016)$, WC $(r=-0.26 ; \mathrm{P}=0.036)$, WHtR $(\mathrm{r}=-0.30) ; \mathrm{P}=0.020)$, AVI $(\mathrm{r}=-0.27$; $\mathrm{P}=0.03)$, ABSI $(\mathrm{r}=-0.31 ; \mathrm{P}=0.015)$, nonlinear positive with BFD $(\mathrm{r}=0.27 ; \mathrm{P}=0.033)$ ), BRI $(\mathrm{r}=0.29$; $\mathrm{P}=0.02)$ and linearly positive with BAI $(\mathrm{r}=0.36 ; \mathrm{P}=0.004)$; thyroid volume is linearly positively associated with age $(\mathrm{r}=0.35 ; \mathrm{P}=0.009)$, nonlinearly positively with $\mathrm{WC} / \mathrm{HC}(\mathrm{r}=0.43 ; \mathrm{P}=0.001), \mathrm{BFD}(\mathrm{r}=0.26 ; \mathrm{P}=0.06)$ and $\mathrm{CI}(\mathrm{r}=0.31 ; \mathrm{P}=0.02)$.

In patients with nodular goiter with $\mathrm{BMI} \geq 35 \mathrm{~kg} / \mathrm{m}^{2}$ thyroid volume is linearly positively associated with BMI $(r=0.71 ; P=0.049)$. In patients with nodular goiter with IRF-1 above the sex-age norm, thyroid volume is nonlinearly positively associated with $\mathrm{WC} / \mathrm{HC}(\mathrm{r}=0.71 ; \mathrm{P}=0.01)$, BAI $(\mathrm{r}=0.66 ; \mathrm{P}=0.03)$ and nonlinearly negative with BFD $(r=-0.52 ; \mathrm{P}=0.01)$. It has been found that BAI explains $82.37 \%$ of the variance of IGF-1 in the general group and more than $90 \%$ of the variance of its level in groups of patients with nodular goiter with high IGF-1 with / without obesity. In patients with nodular goiter with high IGF-1 and obesity, the predictor of increased thyroid volume is BRI, which explains $81.14 \%$ of the variance of its volume.

Conclusions: Patients with nodular goiter with IGF-1 level in blood above the sex-age norm have significantly higher values of anthropometric indicators IR (WHtR, ABSI, BFD and BAI) compared with patients with a normal level of this indicator; in patients with nodular goiter with II degree obesity and above, thyroid volume is significantly associated with BMI; BAI $(\mathrm{R} 2=82.37 \%)$ is a predictor of increased levels of IGF-1 in blood of patients with nodular goiter, regardless of the obesity; BRI (R2 $=81.14 \%$ ) is a predictor of increased thyroid volume in patients with nodular goiter with IGF -1 high level and obesity.

Key words: nodular goiter, anthropometric indicators, insulin resistance.

\section{АНАЛІЗ ЗВ'ЯЗКУ \\ МІЖ АНТРОПОМЕТРИЧНИМИ ІНДИКАТОРАМИ РЕЗИСТЕНТНОСТІ ДО ІНСУЛІНУ ТА ІНСУЛІНОПОДІБНИМ РОСТОВИМ ФАКТОРОМ-1 У ХВОРИХ НА ВУЗЛОВИЙ ЗОБ}

\author{
Мірошніченко О. С. ${ }^{1}$, Микитюк М. Р. ${ }^{1,2}$, Чернявська I. В. ${ }^{1}$, Дубовик В. М. ${ }^{1}$, \\ Селюкова Н. Ю. ${ }^{1}$, Дорош О. Г. ${ }^{1}$, Герасименко В. Л. ${ }^{1}$, Сазонов М. С. ${ }^{1}$ \\ ${ }^{1}$ ДУ «Інститут проблем ендокринної патологї іл. В. Я. Данилевського НАМН України», \\ м. Харків, Україна \\ ${ }^{2}$ Харківська медична академія післядипломної освіти МОЗ Украӥни, \\ м. Харків, Україна \\ myronchik@gmail.com
}

Публікації, що припускають, що вузли щитовидної залози можуть бути пов'язані з інсулінорезистентністю (IP) та метаболічним синдромом, е досить цікавими. В одному з нещодавніх звітів також повідомлялося про збільшення об'єму щитовидної залози та поширеності вузлів у пацієнтів з IP у йододефіцитному регіоні. Мета роботи - проаналізувати зв'язок між антропометричними індикаторами IP та ІФР-1 у паціентів з вузловим зобом.

Матеріали та методи. Обстежено 73 хворих на еутиреоїдний одновузловий (n = 34) та багатовузловий зоб (n = 39) віком від 17 до 74 років $(51,0 \pm 10,6)$ років. Визначали ОТ, ОТ/OC, I/MT, OT/3, IФТ, РЖ, IOT, IК, ІОТ, ІОжТ, ІФР-1, ТТГ, fT , fT $_{3}$. Оцінку об’ему ЩЗ, ї структури, кількості, розмірів і локалізації вогнищевих утворень проводили на ультразвуковому комплексі Aloka SSD-1100 (Японія) з використанням лінійного датчика 7,5 МГц. 
Результати. В загальній вибірці хворих на вузловий зоб ІФР-1 нелінійно негативно асоціюеться з IMT $(\mathrm{r}=-0,30 ; \mathrm{P}=0,016)$, OT $(\mathrm{r}=-0,26 ; \mathrm{P}=0,036)$, OT/3 $(\mathrm{r}=-0,30 ; \mathrm{P}=0,020)$, IOЖ $(\mathrm{r}=-0,27 ; \mathrm{P}=0,03)$, $\mathrm{I} Ф \mathrm{~T}(\mathrm{r}=-0,31 ; \mathrm{P}=0,015)$, нелінійно позитивно з РЖ $(\mathrm{r}=0,27 ; \mathrm{P}=0,033)$, IOT $(\mathrm{r}=0,29 ; \mathrm{P}=0,02)$ та лінійно позитивно з ІОжТ ( $\mathrm{r}=0,36 ; \mathrm{P}=0,004)$; об’ем ЩЗ лінійно позитивно асоціюеться з віком $(\mathrm{r}=0,35$; $\mathrm{P}=0,009)$, нелінійно позитивно з ОT/OC ( $\mathrm{r}=0,43 ; \mathrm{P}=0,001)$, РЖ ( $\mathrm{r}=0,26 ; \mathrm{P}=0,06)$ та IK $(\mathrm{r}=0,31$; $\mathrm{P}=0,02)$. У хворих на вузловий зоб із IMT $\geq 35 \mathrm{kr} / \mathrm{M}^{2}$ об'єм ЩЗ лінійно позитивно асоціюеться з IMT $(\mathrm{r}=0,71 ; \mathrm{P}=0,049)$. У хворих на вузловий зоб з ІФР-1 вище статево-вікової норми об'єм ЩЗ нелінійно позитивно асоціюеться з ОТ/OC $(\mathrm{r}=0,71 ; \mathrm{P}=0,01)$, ІОж Т $(\mathrm{r}=0,66 ; \mathrm{P}=0,03)$ та нелінійно негативно з РЖ ( $\mathrm{r}=-0,52 ; \mathrm{P}=0,01)$. Встановлено, що ІОжТ пояснюе 82,37 \% дисперсії ІФР-1 в загальній групі та більше 90 \% дисперсії його рівня в групах хворих на вузловий зоб з високим ІФР-1 з/без ожиріння. У хворих на вузловий зоб з високим IФР-1 і ожирінням предиктором збільшення об’ему ЩЗ є IOT, який пояснює 81,14 \% дисперсії її об’ему.

Висновки: Хворим на вузловий зоб з рівнем концентрації ІФР-1 в крові вище статево-вікової норми притаманні значуще більш високі значення антропометричних індикаторів IP (OT/3, IФT, РЖ та ІОжТ) порівняно із хворими з нормальним рівнем цього показника; у хворих на вузловий зоб з ожирінням II ступеня і вище об'єм ЩЗ значуще асоційований з IMT; предиктором підвищення рівня концентрації ІФР-1 в крові у хворих на вузловий зоб незалежно від наявності ожиріння е ІОжт $\left(\mathrm{R}^{2}=82,37 \%\right)$; предиктором збільшення об'єму ЩЗ у хворих на вузловий зоб з високим рівнем концентрації IФР-1 та ожирінням є IOT $\left(\mathrm{R}^{2}=81,14 \%\right)$.

К лючові слов : вузловий зоб, антропометричні показники інсулінорезистентності. 